\title{
Penerapan Model Pembelajaran Team Games Tournamen (TGT) pada Pembelajaran Tematik Terpadu Kelas 5 untuk Peningkatan Keterampilan Kolaborasi
}

\author{
Muhamad Surya Hamdani ${ }^{1}$, Mawardi² $^{2}$ Krisma Widi Wardani ${ }^{3}$
}

${ }^{123}$ PGSD FKIP Universitas Kristen Satya Wacana Salaiga

\author{
A R T I C L E I N F 0 \\ Article history: \\ Received 15 August 2019 \\ Received in revised form \\ 20 September 2019 \\ Accepted 10 October 2019 \\ Available online 27 \\ November 2019 \\ Kata Kunci: \\ Tematik terpadu, 2. \\ keterampilan kolaborasi, 3. \\ Model TGT \\ Keywords: \\ Thematic integrated, 2. \\ collaborative skills. 3. Model \\ TGT
}

\begin{abstract}
A B S T R A K
Salah satu permasalahan yang dihadapi dalam pembelajaran tematik di SD Negeri Koripan 01 adalah rendahnya minat belajar, kurang aktifnya siswa mengakibatkan rendahnya keterampilan kolaborasi siswa. berdasarkan permasalahan diatas, penelitian ini bertujuan untuk meningkatkan keterampilan kolaborasi siswa. Melalui model pembelajarn (Teams Games Tournament), Dengan langkahlangkah: penyajian kelas, tim, permainan, pertandingan dan penghargaan kelompok. menggunakn metode Penelitian Tindakan Kelas (PTK) yang dilakukan dua sklus, melalui tahap observasi dokumentasi dan tes instrument, instrumen kolaborasi yang akan ditingkatkan antaralain bisa beradaptasi dalam anggota, bekerja sama, menghargai setiap ide, Bertanggung jawab, ikut berpartisipasi dalam kelompok. Data kualitatif dinyatakan dalam bentuk kata-kata atau simbolsimbol, kuantitatif data yang berbentuk angka. Dari hasil penelitin ini dibuktikan adanya peningkatan dengan data pada pra siklus nilai rata-rata keterampilan kolaboasi dari 61,81 meningkat pada siklus 1 nilai rata-rata menjadi 67,27 dan lebih meningkat lagi pada siklus 2 nilai rata-rata menjadi 83,18 . Dengan demikian hasil tersebut menunjukkan bahwa dengan menerapkan model pembelajaran (TGT) didalam proses pembelajaran dapat meningkatkan keterampilan kolaboasi dan hasil belajar siswa.
\end{abstract}

\section{A B S T R A C T}

One of the problems faced in thematic learning in primary schools is 01 Koripan lack of interest in learning, students are less active student collaboration resulted in low skill based on the above issues, this study aims to improve student collaboration skills. Through learning models (Teams Games Tournament)With these steps: class presentation, team, game, match and group awards. use method Classroom Action Research (CAR) conducted two sklus, through the observation phase of documentation and test instrument, the instrument will be increased collaboration among others can adapt in members, working together, to appreciate each idea, Responsible, participated in the group. The qualitative data is expressed in the form of words or symbols, quantitative data in the form of numbers. From the results of this experiment demonstrated their enhancement ith pre-cycle data on the average value of 61.81 collaboration skills increase in cycle 1 the average value becomes 67.27 and improved further in the second cycle of the average value becomes 83.18. Thus these results indicate that by applying the learning model (TGT) in the learning process it can improve student collaboration skills and student learning outcomes. 


\section{Pendahuluan}

Pendidikan adalah usaha sadar dan terencana untuk mewujudkan suasana belajar dan proses pembelajaran agar peserta didik secara aktif mengembangkan potensi dirinya untuk memiliki kekuatan spritual keagamaan, pengendalian diri, kepribadian, kecerdasan, akhlak mulia, serta keterampilan yang diperlukan dirinya, masyarakat, bangsa, dan negara (UU no 20 tahun 2003 pasal 1 tentang sistem pendidikan). Oleh karena itu, pendidikan merupakan salah satu hal penting untuk menentukan maju mundurnya suatu bangsa, maka untuk menghasilkan sumber daya manusia sebagai subjek dalam pembangunan yang baik, diperlukan modal dari hasil pendidikan itu sendiri (Hakim, 2013). Dalam upaya meningkatkan kualitas pendidikan, kualitas guru merupakan salah satu komponen yang mempunyai peran sangat penting. Kegiatan guru mempengaruhi keberhasilan kegiatan pendidikan. Guru harus menciptakan proses belajar dengan baik sesuai tujuan pendidikan dan memberikan dorongan untuk potensi belajar peserta didik. Guru hendaknya juga mampu membimbing dan memfasilitasi peserta didik, agar mereka dapat memahami kekuatan serta kemampuan yang ada pada dirinya, selanjutnya memberikan motivasi agar peserta didik terdorong untuk belajar sebaik mungkin sehingga dapat mewujudkan keberhasilan berdasarkan kemampuan yang mereka miliki (Aunurrahman, 2010:13). Dalam proses pembelajaran, guru sebagai pendidik harus bertanggung jawab terhadap hasil belajar peserta didik dan pengetahuan peserta didik terkait dengan materi yang telah dipelajarinya (Saktiningsih, 2015). Namun kenyataan di lapangan proses pembelajaran masih banyak permasalahan dan belum dapat dilaksanakan dengan baik sesuai yang diharapkan. Faktor yang menyebabkan hal ini yaitu proses pembelajaran yang dilakukan oleh guru, dan sulitnya materi yang dipelajari sehingga kurangnya motivasi dalam diri peserta didik. Padahal dalam proses pembelajaran, motivasi merupakan salah satu aspek yang sangat penting (Hikmah, 2018).

Pendidikan memiliki peran penting dalam kemajuan dan perkembangan bangsa. Para generasi penerus bangsa hendaknya menyadari akan tanggung jawab yang ada dibenak mereka dalam rangka meningkatkan kualitas sumber daya manusia yang ada. Pada kenyataannya proses pembelajaran matematika tidak selamanya berjalan efektif. Hal ini dikarenakan tidak semua materi pelajaran matematika mudah dipahami oleh siswa dan mudah disampaikan oleh guru, sehingga seringkali kesulitan muncul pada saat mempelajari materi - materi tertentu. Pada dasarnya pelajaran matematika di sekolah dasar menanamkan konsep - konsep dasar matematika sederhana yang menjadi pengetahuan awal sebelum siswa belajar di tingkat yang lebih tinggi. Dengan demikian guru sebagai penyampai pengetahuan harus yakin dan mampu mengajarkan materi dasar dengan baik dan benar. Hal ini yang juga penting dilakukan oleh guru adalah bagaimana menciptakan pembelajaran matematika yang menyenangkan sehingga mampu memunculkan kecintaan dan kesukaan anak pada pelajaran ini. Salah satu hal yang dapat dilakukan oleh guru untuk mencapai tujuan di atas adalah dengan melakukan variasi pembelajaran. Jika selama ini guru lebih banyak menggunakan pembelajaran langsung, maka ada baiknya guru mencoba menerapkan metode atau model pembelajaran lainnya. Atas permasalahan tersebut, diadakan penelitian bertujuan untuk mengetahui pengaruh model pembelajaran kooperatif tipe Team Games Turnamen (TGT) terhadap hasil belajar matematika siswa SD dalam bentuk penelitian eksperimen. Berdasarkan latar belakang masalah di atas, maka dirumuskan masalah yaitu: apakah ada pengaruh model pembelajaran kooperatif tipe Team Games Turnamen (TGT) terhadap hasil belajar matematika aspek kognitif, afektif, dan psikomotor siswa SD. Tujuan penelitian ini yaitu untuk mengetahui pengaruh model pembelajaran kooperatif tipe Team Games Turnamen (TGT) terhadap hasil belajar matematika aspek kognitif, afektif, dan psikomotor siswa SD. Model pembelajaran ini merupakan salah satu model pembelajaran kooperatif yang menggunakan tim kerja dan turnamen mingguan yang berupa permainan akademik yang dimainkan oleh siswa dengan anggota tim lain untuk menyumbangkan poin bagi skor timnya tanpa harus ada perbedaan status. Peran siswa disini sebagai tutor sebaya dan mengandung unsur permainan (Slavin, 2011: 13). Model pembelajaran ini pemindahan pengetahuan secara langsung oleh guru kepada peserta didik secara langsung, misalnya melalui ceramah, demonstrasi, dan tanya jawab (Roy Killen dalam Kemendiknas, 2010: 23). Model pembelajaran langsung memiliki karakteristik sebagai berikut: a) Transformasi dan keterampilan secara langsung. b) Pembelajaran berorientasi pada pembelajaran tertentu. c) Materi pembelajaran yang terstruktur. d) Lingkungan belajar yang telah tersruktur. e) Distruktur oleh guru. (Departemen Pendidikan Nasional, 2010:24 (Cahyaningsih, 2017).

Teams Games Tournament (TGT) adalah salah satu tipe belajar kooperatif dimana dalam Teams Games Tournament para siswa dibagi dalam tim belajar yang terdiri atas empat orang yang berbeda-beda tingkat kemampuan, jenis kelamin, dan latar belakang etniknya. Selanjutnya guru menyampaikan pelajaran, siswa belajar dalam kelas dan memastikan bahwa semua anggota tim telah menguasai pelajaran. Setelah itu siswa memainkan game akademik dengan anggota tim lain untuk menyumbang point bagi skor timnya. Siswa memainkan game ini bersama tiga orang pada "Meja turnamen", dimana 
ketiga peserta dalam satu meja turnamen ini adalah para siswa yang memiliki rekor nilai terakhir yang sama. Sebuah prosedur "menggeser kedudukan" membuat permainan ini cukup adil. Tim dengan kinerja tinggi mendapatkan sertifikat atau penghargaan dari tim lain (Slavin, 2005). Menurut Slavin (2005) TGT terdiri atas lima komponen yaitu: Presentasi Kelas, Tim, Game, Tournament, Rekognisi Tim. Berdasarkan uraian diatas dapat disimpulkan bahwa langkah-langkah model pembelajaran Teams Games Tournament (TGT) adalah sebagai berikut: Guru menyajikan materi pelajaran. Sebelum siswa dibagi kedalam kelompok, terlebih dahulu guru menyajikan materi pelajaran sesuai tujuan pembelajaran yang diinginkan. Selain itu guru juga harus menyiapkan kartu soal untuk games tournament dan lembar kerja siswa; Bekerja kelompok (team). Siswa dibagi atas beberapa kelompok (tiap kelompok anggotanya 4-5 orang). Setiap kelompok mengerjakan tugas dalam LKS yang dibagikan guru. Apabila ada anggota kelompok yang tidak mengerti dengan tugas yang diberikan, maka anggota kelompok lain bertugas membantu menjelaskannya; Permainan (games); Pemberian hadiah (Drayatun, 2017).

Pembelajaran Dari hasil observasi dalam pelaksanan pembelajaran tematik di kelas 5 SD Negeri Koripan 01 dan wawancara dengan guru mengatakan siswa mengalami kesulitan didalam melakukan kegiatan kelompok, hal ini dikarenakan siswa kurang melakukan kegiatan diskusi secara tim atau kelompok dalam pembelajaran. Guru kelas jarang menerapkan kerja kelompok dalam menggunakan suatu model pembelajaran. membuat keterampilan siswa tidak berkembang salah satunya keterampilan kolaborasi. Pemelajrn sepeti ini membuat siswa cepat merasa bosan tidak dapat berkonsentrasi dalam waktu yang lama. Hal ini dibuktikan dengan seringnya siswa meminta ijin kekamar mandi di saat pembelajaran berlangsung. Itu semua disebakan karena kurangnya variasi pembelajaran yang digunakn guru.

Salah satu alternatif pemecahan permasalahan yang ada, adalah dengan menggunakan model pembelajaran Team Games Tournamen (TGT) model pembelajaran ini juga direkomendasikan dalam Lampiran Permendikbud No. 22 Tahun 2016 tentang Standar Proses Pendidikan Dasar dan Menengah Menurut Hamdani (2011: 31) Dalam pembelajaran kooperatif TGT, dengan sistem siswa diajak belajar bersama dengan kelompok-kelompok kecil yang saling membutuhkan, membantu satu sama lain. Kelas dibentuk dalam beberapa kelompok, setiyap kelompok terdiri atas empat sampai enam orang siswa, mempunyai kemampuan heterogen (berbeda). Bermanfaat dapat melatih siswa menerima perbedaan pendapat, bekerja sama dengan teman yang berbeda latar belakangnya. Berdiskusi dengan teman, mengenai materi yang di berikan guru, dan memastikan semua anggot memahaminya. Diharapkan melalui model pembelajaran Team Games Tournamen (TGT) dapat meningkatkan keterampilan kolaborasi siswa penelitian diharapkan juga dapat memberikan manfaat, Bagi guru, untuk meningkatkan kegiatan pembelajaran di kelas supaya dapat menjadi bahan pertimbangan / pemikiran dalam perkembangan prestasi belajar, Bagi sekolah, untuk meningkatkan kualitas pembelajaran sekolah dalam menggunakan pendekatan pembelajaran yang sesuai dengan kegiatan belajar-mengajar.

Pembelajaran tematik pada dasarnnya merupakn suatu model pembelajaran terpadu, dengan menggunakan tema untuk dapat mengaitkan beberapa mata pelajaran agar dapat memberikan pengetahuan yang lebih baik kepada siswa (Trianto, 2011: 147). Sedangkan menurut Rusman, pembelajaran tematik merupakan satu model dalam pembelajaran terpadu, merupakan sistem pembelajaran yang menjadikan siswa, aktif mencari, dapat menemukan manfaat serta prinsip- prinsip belajar yang holistik, bermakna, baik secara individual maupun kelompok, (Rusman, 2011: 254) Dari pengertian diatas dapat di Tarik kesimpulan, Pembelajaran tematik integratif merupakan pembelajaran yang berpuat pada tema, menjadi pemersatu beberapa mata pelajaran sekaligus, didalam satu kali tatap muka. Pelaksanaan pembelajaran tematik integrative dilakukan dengan mengambil tema yang sudah dipilih, untuk dapat dimanfaatkan oleh guru, sesuai dengan kebutuhan peserta didik. perbandingkan dengan pelajaran konvensional.

Slavin (dalam Isjoni, 2014:12) model pembelajaran kooperatif dimana siswa bekerja dalam kelompok-kelompok kecil yang berjumlah 4-5 orang secara kolaboratif sehingga dapat merangsang siswa lebih giat dalam belajar untuk mencapai tujuan pembelajaran yang dirumuskan dalam menyelesaikan tugas kelompoknya. Semua anggota kelompok saling bekerja sama dan saling membantu untuk memahami materi pembelajaran. Agus Suprijono (2014: 54) Pembelajaran kooperatif adalah konsep yang lebih luas meliputi semua jenis kerja kelompok termasuk bentuk yang lebih dipimpin oleh guru atau diarahkan oleh guru.

Model pembelajaran TGT merupakan salah satu tipe model pembelajaran kooperatif. Slavin (2005: 163) mengemukakan TGT adalah model pembelajaran kooperatif menggunakan turnamen akademik dan menggunakan kuis-kuis, dimana para siswa berlomba sebagai wakil tim mereka dengan anggota tim lain yang kinerja akademik sebelumnya setara seperti mereka. Menurut Asma (2006: 54) model TGT adalah suatu model pembelajaran oleh guru dan diakhiri dengan memberikan sejumlah pertanyaan kepada siswa. Setelah itu siswa pindah ke kelompok masing-masing untuk mendiskusikan dan menyelesaikan 
pertanyaan-pertanyaan atau masalah-masalah yang diberikan guru. Sebagai ganti tes tertulis siswa akan bertemu di meja turnamen.

Ada beberapa langkah dalam penggunaan model pembelajaran TGT yang perlu diperhatikan. Langkah-langkah penggunaan model pembelajaran TGT menurut Slavin (2005: 170) sebagai berikut: a) Presentasi di kelas; b) Belajar tim. Para siswa mengerjakan lembar kegiatan dalam tim mereka untuk menguasai materi; c) Turnamen. Para siswa memainkan game akademik dalam kemampuan yang homogeny; d) Rekognisi tim. Skor tim dihitung berdasarkan skor turrnamen anggota tim, dan tim tersebut akan direkognisi apabila mereka berhasil melampaui kriteria yang telah ditetapkan sebelumnya.

Setiap model pembelajaran mempunyai kelebihan dan kelemahan masing-masing. Untuk itu, guru dituntut untuk bisa memilih model pembelajaran yang tepat dengan menyesuaikan kebutuhan dan kondisi siswa. Berikut pemaparan kelebihan dan kelemahan Model Pembelajaran Kooperatif Tipe Teams Games Tournament (TGT) menurut Suarjana (2000: 10): kelebihan pembelajaran (TGT) a) Lebih meningkatkan pencurahan waktu untuk tugas; b) Mengedepankan penerimaan terhadap perbedaan individu; c) Dengan waktu yang sedikit dapat menguasai materi secara mendalam; d) Proses belajar mengajar berlangsung dengan keaktifan dari siswa; e) Mendidik siswa untuk berlatih bersosialisasi dengan orang lain; f) Motivasi belajar lebih tinggi; g) Hasil belajar lebih baik. h) Meningkatkan kebaikan budi, kepekaan dan toleransi.

Kelemahan pembelajaran (TGT) a) Bagi guru Sulitnya pengelompokan siswa yang mempunyai kemampuan heterogen dari segi akademik. Kelemahan ini akan dapat diatasi jika guru yang bertindak sebagai pemegang kendali, teliti dalam menentukan pembagian kelompok. Dan waktu yang dihabiskan untuk diskusi oleh siswa cukup banyak sehingga melewati waktu yang sudah ditetapkan. Kesulitan ini dapat diatasi jika guru mampu menguasai kelas secara menyeluruh; b) Bagi siswa masih adanya siswa berkemampuan tinggi kurang terbiasa dan sulit memberikan penjelasan kepada siswa yang lainnya. Untuk mengatasi kelemahan ini, tugas guru adalah membimbing dengan baik siswa yang mempunyai kemampuan akademik tinggi agar dapat dan mampu menularkan pengetahuannya kepada siswa yang lain.

Hasil Penelitian Yang pernah dilakukan Bambang Sumantri. (2014) Melakukan penelitian tentang meningkatkan kualitas pembelajaran dan hasil pembelajaran pada mata pelajaran PKn melalui model pembelajaran kooperatif tipe Teams Games Tournament (TGT) dapat meningkatkan motivasi di awal pembelajaran untuk meningkatkan minat dan konsentrasi belajar, dengan penyampaian, penjelasan materi Dari segi hasil belajar siswa mengalami peningkatan yang berarti, Yanti Purnamasari (2013)pengaruh model pembelajaran Teams Games Tournament (TGT) terhadap kemandirian belajar dan kemampuan penalaranm matematika peserta didik SMP N 1 Kota Tasikmalaya. Hasi penelitian dan pembahasan menu njukan pembelajran TGT mampu meningkatkan kemampuan beljar dan penalaran. Menurut Zumaroh, E (2017) Penerapan model pembelajaran kooperatif tipe Teams Games Tournament dapat meningkatkan motivasi dan hasil belajar siswa

Menurut Ted Panitz (1996) menjelaskan bahwa pembelajaran kolaboratif adalah suatu filsafat personal, tidak hanya sekadar teknik pembelajaran di kelas. Menurutnya, kolaborasi merupakan, filsafat interaksi dan sebuah gaya hidup dengan menjadikan kerjasama merupakan struktur interaksi yang didesain sedemikian rupa, yang dapat memudahkan usaha agar mencapai keberhasilan bersama. Pada segala situasi, ketika sejumlah orang berada didalam suatu kelompok, kolaborasi merupakan suatu cara untuk bisa berhubungan, dengan lebih menghormati dan menghargai kemampuan dan pendapat semua anggota kelompok. Di dalamnya terdapat pembagian kewenangan dan diterimanya tanggung jawab di antara anggota kelompok, melaksanakan tindakan kelompok.

Indicator yang dipakai peneliti mengunakan pendapat Greenstein (2012: 28) mengumpulkan dan menyintesis berbagai indikator keterampilan berkolaborasi sebagai berikut: a) Bekerja secara produktif dengan orang lain; b) Berpartisipasi dan berkontribusi secara aktif; c) Seimbang dalam mendengar dan berbicara, menjadi yang utama dan menjadi pengikut dalam kelompok; d) Menunjukkan fleksibilitas dan berkompromi; e) Bekerja secra kolega dengan berbagai tipe orang; f) Menghormati ide-ide orang lain; g) Menunjukkan keterampilan pengambilan satu pandangan atau perspektif; h) Berkomitmen untuk mendahulukan tujuan kelompok; i) Mempertimbangkan kepentingan dan kebutuhan kelompok yang lebih besar; j) Menghargai kontribusi masing-masing anggota kelompok; k) Mengakui dan menggunakan kekuatan anggota kelompok; l) Mencocokkan tugas dan pekerjaan berdasarkan kekuatan dan kemampuan individu anggota kelompok; m) Bekerja sama untuk menyelesaikan masalah dan menghasilkan ide-ide dan produk baru; n) Bertanggung jawab bersama untuk menyelesaikan pekerjaan; o) Memprioritaskan kebutuhan dan tujuan, baik individu maupun kelompok; p) Bekerja dengan orang lain untuk membuat keputusan yang mencakup pandangan beberapa individu; q) Mengidentifikasi area kesepakatan dan ketidaksepakatan; r) Berpartisipasi secara hormat dalam diskusi, debat, dan perbedaan pendapat; s) Mengontrol emosi sendiri; t) Berkontribusi dalam kelompok untuk resolusi konfllik. 


\section{Metode}

Lokasi dari penelitian ini dilaksanakan di kelas 5 di SD Negeri Koripan 01 pada semester II. Terletak semangu, koripan, susukan, semarang Jawa Tengah. Subjek penelitian ini adalah siswa kelas 5 di SD Negeri Koripan 01. Jenis penelitian yang digunakan dalam penelitian ini adalah penelitian tindakan kelas. dalam penelitian ini menggunakan model Kemmis yang dikembangkan oleh Stephen Kemmis dan Robin Mc Taggart (Arikunto, Suhardjono, Supardi: 2007). Penelitian tindakan ini dilakukan dalam beberapa siklus. Setiap siklus meliputi beberapa tahapan yang meliputi perencanaan (planning), tindakan (action), pengamatan (observation) dan refleksi (reflection)dalam suatu spiral yang saling terkait. Adapun model penelitian tindakan kelas menurut Kemmis menggunakan sistem siklus, yang terdiri dari tiga tahap yaitu: 1) Perencanaan (planning); 2) Pelaksanaan dan pengamatan (acting and observasing); 3) Refleksi (reflecting)

Teknik pengumpulan data dalam penelitian adalah dengan menggunakan metode observasi dokumentasi dan tes. Data yang diperoleh kemudian dianalisis secara kualitatif dan kuantitatif. Data kualitatif dinyatakan dalam bentuk kata-kata atau simbolsimbol, sedangkan kuantitatif adalah data yang berbentuk angka. Instrumen penelitian yang digunakan berupa lembar tes dan lembar observasi perencanaan pembelajaran serta pelaksanaan pembelajaran.

\section{Hasil dan Pembahasan}

Pelaksanaan penelitian ini dilaksanakan sebanyak 2 siklus, tapi sebelum siklus itu dilakukan ada kegiatan pra siklus atau observasi untuk dapat mengetahui data awal sebagai patokan sebelum kegiatan siklus dilakukan. Dalam setiap siklusnya ada Tahapan yang dilaksanakan dalam setiap siklus meliputi perencanaan, pelaksanaan, observasi dan refleksi. Sedangkan pada setiap akhir siklus diadakan tes evaluasi untuk mengetahui presentase ketuntasan yang telah dicapai, serta diberi angket kolaborasi untuk mengetahui sejauhmana keterampilan kolaborasi siswa. Diharapkan dalam setiap prosenya mengalami peningkatan agar mampu memperbaiki dari setiap prosenya. Dalm penelitianini sudah menglami peningkatan dari pra siklus ke siklus 1 begitu pula pada siklus 1 ke silus 2 mengalami peningkatan, Dapat dilihat pada tabel yang dapat memperjelas peningkaan keterampilan kolaborasi siswa pada pra siklus ke siklus 1 dan ke siklus 2 .

Tabel 1. Peningkatan keterampilan kolaborasi dari pra siklus, siklus 1 dan siklus 2

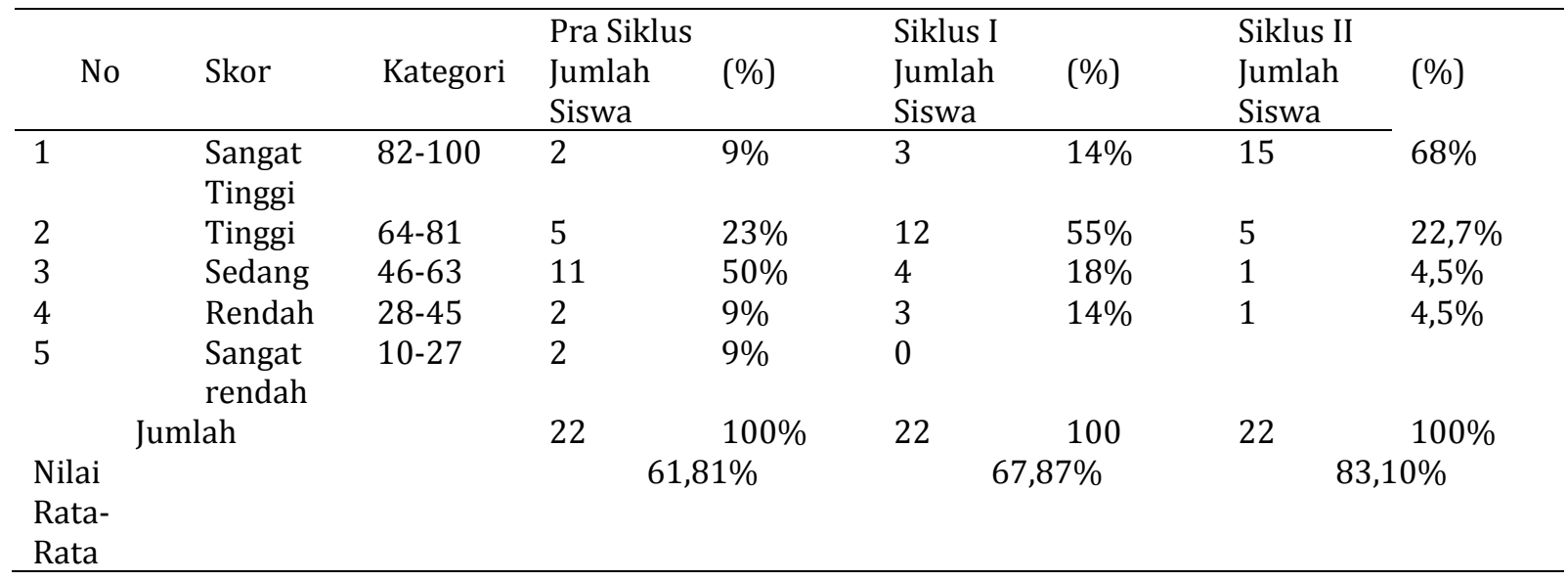

Dari tabel di atas dapat dilihat peningkatannya dari pra siklus sampai siklus 2 untuk memperjelas dapat juga dilihat pada gambar diagram di bawah. 


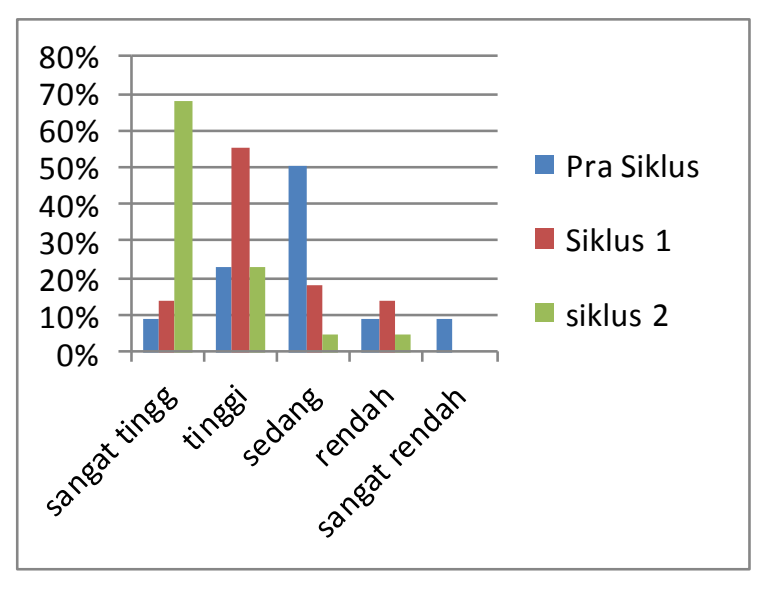

Gambar 1 Peningkatan keterampilan kolaborasi dari pra siklus, siklus 1 dan siklus 2

Diagram tersebut menjelaskan bahwa tingkat keterampilan kolaborasi siswa dari pra siklus sampai siklus 2 mengalami peningkatan. Pada pra siklus keterampilan kolaborasi (2 dari 22 siswa) memiliki keterampilan kolaborasi sangat tinggi yaitu 6 siswa (9\%), (5 siswa dari 22 siswa) memiliki keterampilan kolaborasi tinggi yaitu $23 \%$, (11 siswa dari 22 siswa) memiliki keterampilan kolaborasi sedang yaitu 50 \%, (2 siswa dari 22 siswa) memiliki keterampilan kolaborasi rendah yaitu 9\%. Pada siklus I(15 dari 20 siswa) memiliki keterampilan kolaborasi sangat tinggi yaitu 75 \%, (2 siswa dari 22 siswa) memiliki keterampilan kolaborasi sangat rendah yaitu 9\%. Pada siklus 1 (3 siswa dari 22 siswa) memiliki keterampilan kolaborasi sangat tinggi yaitu $14 \%$, (12 siswa dari 22 siswa) memiliki keterampilan kolaborasi tinggi yaitu 55\%, (4 siswa dari 22 siswa) memiliki keterampilan kolaborasi sedang yaitu 18\%, (3 siswa dari 22 siswa) memiliki keterampilan kolaborasi rendah yaitu 14\%, \%, (0 siswa dari 22 siswa) memiliki keterampilan kolaborasi sedang yaitu 0\%. Pada siklus II (15 siswa dari 22 siswa) memiliki keterampilan kolaborasi sangat tinggi yaitu 68.2\%, (5 siswa dari 22 siswa) memiliki keterampilan kolaborasi tinggi yaitu 22,7\%, (1 siswa dari 22 siswa) memiliki keterampilan kolaborasi sedang yaitu 4.5 \%. (1 siswa dari 22 siswa) memiliki keterampilan kolaborasi rendah yaitu 4.5\%. (0 siswa dari 22 siswa) memiliki keterampilan kolaborasi sangat rendah yaitu $0 \%$

Dengaan nilai rata-rata juga mengalaami peningkatan dari pra siklus (61.81\%) naik pada siklus 1 menjadi (67.87\%) dan di siklus 2 juga mengaami peningkatan menjdi $(83.18 \%)$ Berdasarkan observasi dan refleksi tindakan yang telah dilakukan oleh guru, pelaksanaan tindakan pembelajaran dengan menggunakan model pembelajaran TGT telah berjalan sesuai dengan yang diharapkan. Penggunaan model pembelajaran TGT juga terbukti dapat meningkatkan ketrampilan kolaborasi kelas 5 di SD Negeri Koripan 01 pada mata pelajaran.

\section{Simpulan dan Saran}

Berdasarkan hasil penelitian yang dilakukan pada kelas 5 SD Negeri Koripan 01 semester II tahun pelajaran 2018/2019, dapat disimpulkan bahwa penerapan metode Teams Games Tournament (TGT) dapat meningkatkan keterampilan kolaborasi dan hasil belajar siswa pada Tema 8 Lingkungan Sahabat Kita, Sub tema 1 Manusia dan Lingkungan. Hal ini dibuktikan dengan adanya peningkatan keterampilan kolaborasi siswa ditunjukkan pada rata-rata hasil observasi pada pra siklus sebesar 61,81 dengan kriteria sedang, pada siklus I meningkat sebesar 67,27 dengan kriteria sedang dan pada siklus II meningkat menjadi sebesar 83,18 dengan kriteria tinggi. Dengan demikian penelitian ini dikatakan berhasil karena didalam pelaksanaannya mengalami peningkatan keterampilan kolaborasi dan hasil beljar siswa dengan jumlah siswa yang mencapai nilai sangat baik 15 orang (68,2\%) pada keterampilan kolaborasi dan 20 siswa (90\%) mengalami ketuntasan pada hasil belajar

Saran Untuk Para guru maupun calon guru agar dpat terbiasa menerapkan suatu model pembelajaran dalam kelas agar siswa-siswi mendapat berbagi variasi dalam pembelajaran siswa tidak bosan dalam mengikuti pembelajaran, sehingga keterampilan kolaborasi pembelajaran siswa bahkan hasil belajarnya dapat meningkat. Untuk kepala sekolah hendaknya memberikan rekomendasi para guru agar dapat mengunakan beberapa model pembelajaran terutma (Teams games Tournament) bagi siswa diharap lebih aktif dan mampu mempraktekan dalam kehidupan bagi penulis diharap bisa lebih mengembankan penelitian yang lebih luas 


\section{Daftar Rujukan}

Affan, A. (2010). Penerapan pembelajaran Kooperatif Kolaborasi Model Quiz-Quiz Trade Danteam Game Tournamentuntuk Meningkatkan Hasil Belajar, Keaktifan Belajar Dan Self Esteem. Dosen Pendidikan Ekonomi FKIP Universitas Kanjuruhan Malang Jurnal Inspirasi Pendidikan.

A'yuningsih, D. Q., Suardana, I. N., \& Suwenten, I. M. (2017). Penerapan Model Pembelajaran Kooperatif Tipe TGT (Teams Games Tournament) Untuk Meningkatkan Motivasi Dan Hasil Belajar Peserta Didik. Jurnal Pendidikan Kimia Indonesia, 1(2), 37-47.

Bambang, S. (2014). Peningkatan Kualitas Pembelajaran Pkn Melalui Model Pembelajaran Kooperatif Tipe Teams Game Tournamen (Tgt) Pada Siswa Kelas Iii Sd Negeri Pelem 2 Ngawi journal media prestasi

Cahyaningsih, Ujiati. 2017. Pengaruh Model Pembelajaran Kooperatif Tipe Team Games Tournament (Tgt) Terhadap Hasil Belajar Matematika Siswa Sd . Jurnal Cakrawala Pendas Vol. 3 No.1 Edisi Januari 2017

Damayanti, S., \& Apriyanto, M. T. (2017). Pengaruh Model Pembelajaran Kooperatif Tipe Teams Games Tournament Terhadap Hasil Belajar Matematika. Jkpm (Jurnal Kajian Pendidikan Matematika), 2(2), 235-244.

Drayatun, Salma. 2017. Penerapan Model Pembelajaran Kooperatif Tipe Tgt Untuk Meningkatkan Aktivitas Dan Motivasi Belajar Siswa Kelas Viid Smp Negeri 1 Kokop . Jurnal Pena Sains Vol. 4, No. 1, April 2017

Hikmah, Msy. 2018. Penerapan Model Pembelajaran Team Games Tournament (Tgt) Terhadap Motivasi Dan Hasil Belajar Peserta Didik Pada Materi Dunia Hewan Kelas X Di Sma Unggul Negeri 8 Palembang . Jurnal Pembelajaran Biologi, Volume 5, Nomor 1, Mei 2018

Fitri, I. (2013). Kompetensi Pedagogik Mahasiswa Dalam Mengelola Pembelajaran Tematik Integratif Kurikulum 2013 Pada Pengajaran Micro Di Pgsd Uad Yogyakart jurnal profesi pendidikan dasar. 87-94.

Ginting, S. (2017). Penerapan Model Pembelajaran Kooperatif Tipe Team Games Tournament (TGT) Untuk Meningkatkan Kompetensi Sikap Sosial Siswa.Peningkatan Motivasi Belajar Siswa.

Iktikaviana, N. L. (2012). Penggunaan Model Pembelajaran Team Game Tournament (TGT) Untuk Meningkatkan Hasil Belajar Siswa Materi Operasi Hitung Bilangan Bulat Positif Dan Negatif Siswa Kelas Iv Sdn Bandung 02 Gedeg Mojokerto (Doctoral Dissertation, University Of Muhammadiyah Malang).

Maisaroh, S. (2011). Upaya Peningkatkan Motivasi Dan Prestasi Belajar Ips Melalui Model Pembelajaran Kooperatif Tipe Teams Games Tournament. Dinamika Pendidikan, 6(2), 150-169.

Nunuk, S. (2012). Implementasi Model Pembelajaran Kolaboratif Untuk Meningkatkan Ketrampilan Sosial Siswa. Dosen Pada Proram Studi Teknologi Pendidikan Program Pascasarjana UNS

Purnamasari, Y. (2013). Pengaruh Model Pembelajaran Kooperatif Tipe Teams Games-Tournament (TGT) Terhadap Kemandirian Belajar Dan Peningkatan Kemampuan Penalaran Dan Koneksi Matematik Peserta Didik Smpn 1 Kota Tasikmalaya (Doctoral Dissertation, Universitas Terbuka).

Parendrarti, R. (2009). Aplikasi Model Pembelajaran Kooperatif Tipe TGT (Teams-Games-Tournament) Dalam Meningkatkan Motivasi Dan Hasil Belajar Biologi Siswa Kelas Xi Ipa Sma Muhammadiyah 2 Surakarta Tahun Ajaran 2008/2009 (Doctoral Dissertation, Universitas Muhammadiyah Surakarta Perpustakaan).

Rusnadi, N. M., \& Arini, D. P. P. N. W. (2013). Penerapan Model Pembelajaran Kooperatif Tipe Team Games Tournament Untuk Meningkatkan Kemampuan Berpikir Kritis Dan Hasil Belajar Ipa. Mimbar Pgsd Undiksha, 1(1).1-10 
Susyanto, A. D. (2015). Upaya Meningkatkan Hasil Belajar Matematika Melalui Pembelajaran Kooperatif Tipe Team Games Tournamen Pada Siswa Kelas V Sd N 1 Jembangan Poncowarno Kebumen. Universitas PGRI Yogyakarta.

Sumantri, B. (2014). Peningkatan Kualitas Pembelajaran Pkn Melalui Model Pembelajaran Kooperatif Tipe Teams Game Tournamen (TGT) Pada Siswa Kelas III SD Negeri Pelem 2 Ngawi. Media Prestasi, 13(1). 20-30

Triyani, A. N. (2009). Model Pembelajaran Kooperatif Tipe Teams-Games-Tournament (TGT) Sebagai Upaya Meningkatkan Keaktifan Belajar Matematika Siswa Pada Pokok Bahasan Peluang Dan Statistika Di Smp Negeri 4 Depok Yogyakarta Kelas Ix C. Universitas Negeri Yogyakarta, Yogyakarta.

Wilujeng, S. (2013). Peningkatan Aktivitas Dan Hasil Belajar Siswa Melalui Model Teams Games Tournament (TGT). Journal Of Elementary Education, 2(1). 45-53

Zumaroh, E., Widana, I. D., \& Muliani, N. L. (2017). Penerapan model pembelajaran kooperatif tipe teams games tournament (TGT) pada pembelajaran kimia untuk meningkatkan motivasi dan hasil belajar siswa. Jurnal Pendidikan Kimia Indonesia, 1(1), 30-36. 